\title{
CHANGE OF PUBLISHER
}

At the ASTIN General Assembly on the occasion of the International Congress of Actuaries 1988 in Helsinki the editors informed participating members about the take-over of TIETO, the former publisher of the ASTIN Bulletin, by Basil Blackwell, a reputable UK publishing house. Although the information about the take-over took us by surprise, we saw no reason to believe that this would adversely affect our Bulletin. Unfortunately, however, as it turned out later, the ASTIN Bulletin did not get the necessary backing from Basil Blackwell. Thus for instance, on November 15, 1988, which was supposed to be the publication date of issue 18.2, the Bulletin was not even typeset. ASTIN readers therefore received issue 18.2 only by the end of January 1989, for which we would like to apologize.

Given these circumstances, the editors, together with the ASTIN Chairman, decided to terminate relations with Basil Blackwell.

The editors consider themselves fortunate to have found a new competent publisher in Ceuterick. This firm is not unknown to ASTIN members, as it already prints the IAA Bulletin and the IAA-Index.

We look forward to working with Ceuterick and are confident of a good and fruitful relationship.

The Editors 